Fleissner's plea that "the Lord does not 'promise' eternity . . . outright to anyone" (such phrasing was altogether commonplace). Many such pitfalls can be avoided when our critical hypotheses are informed by a close familiarity with the literary, linguistic, and bibliographical customs of the age, as evident even in noncanonical texts.

What all three letters finally indicate most forcibly, I think, is that "W. H." will never rest in peace while questions remain about Shakespeare's Sonnets. So long as men can breathe or eyes can see, so long lives Mr. W. H. - and that's okay with me. The continuing debate over these perplexing sonnets, including even the most outlandish hypotheses, registers the undying vigor of Shakespeare studies and of the ideological structures that support them and us. Whatever it was that Thomas Thorpe attempted to say in 1609, William Shakespeare has become, for better or worse, our ever-living poet.

Donald W. Foster

Vassar College

\section{Wister's Typology}

\section{To the Editor:}

In " "When You Call Me That . . .: Tall Talk and Male Hegemony in The Virginian" (102 [1987]: 66-77), Lee Clark Mitchell aims to turn the reader of Owen Wister's novel "from text to context" (67) in order to locate the contributing source of the novel's original and continuing appeal; but by settling only for the unique suffrage legislation in Wyoming at the time of publication (1902), Mitchell misses the genuine crux of the issue of context. Moving outward from text to context, the reader passes, and would have passed then, through literary, historical, and cultural contextual spheres (I'll group these under one name: typological) far richer in connotative and suggestive power than what Mitchell sketches in part 4 of the essay.

We miss a clue to the expanded context through Mitchell's neglect of the American historical and cultural plan Wister clearly wanted to implement in and through the novel. Quoting from Wister's "To the Reader," Mitchell notes that The Virginian is aimed at "Wyoming between 1874 and 1900"' (75n8), but he neglects a previous and more revealing authorial statement of design: "For Wyoming between 1874 and 1900 was a colony as wild as was Virginia one hundred years earlier" (The Virginian, New York: Airmont, 1964, 11). Clearly, Wister wanted us to read his rendition of the current history of the West as a palimpsest on which a faint but definite appearance of southern, specifically Virginian, history of the Revolutionary era also shone.

Perhaps rot quite as clearly, Wister also wanted to renarrate the myth of the birth of the Union with a redefi- nition of the Virginian fatherhood at its origin. The New England tradition, as we learn from reviews and other published sources at the time, was suspected of suffering a pernicious national anemia: the genteel ideal had its detractors. No more national gumption was expected from that quarter. In a note to the reader, Wister reveals his side in the controversy between gentility and the strenuous life when he complains that the eastern male wastes his substance in a Wall Street office or a Newport spa. His cowpunching Southerner infuses the needed muscular, and glandular, vitality. In this physioliterary intention Wister was not alone or original.

Henry Adams, in his novel Democracy (1885), had nominated, with a certain degree of protective irony, the descendant of the bloodline of Washington and Lee, Carrington, to clean up the "scum" spilling from the misbegotten political world of the Grant era. More to the present point of precursors for Wister is Henry James's Bostonians (1886). James had deliberately used a Mississippian, Basil Ransom, to counter and shout down the "cant" of equality that had enervated and unmanned the age. Ransom's rhetoric is brutal and aristocratic, erotically successful in wooing Verena Tarrant, and anachronistic. James knew more about the typological material he was using than Wister did. Wister, then, is not the first to show a southern lover cleverly and incessantly using words to crush the opposition of the lady.

Wister's designation "Virginian," I would further argue, does not exactly leave his main figure "unnamed." Readers would have needed no more than the title; an actual name would have been superfluous. We know enough about the tall, handsome, mounted hero, this knight who carries away tokens of his feminine conquests (flowered handkerchiefs and strands of golden hair), who comes from "somewhere across the vast horizon," like the Arthurian original, covered with conveniently pale dust that makes him the image of the armored knight. The typology functions consistently, perhaps even too overtly.

To see the Virginian's domination of Molly in terms of gender or rhetoric is to see only parts of the Wisterian plan. Molly is a New England woman with female precursors Wister traces back to 1777 , the age of the so-called founding fathers. That Molly's great-aunt consciously registers the Virginian's erotic energy before Molly does indicates a significant additional wrinkle to Wister's plan. Molly must turn back at least two generations in order to go forward with the erotic, historical (Wisterical) scheme. The Virginian's reverent kiss of the portrait of Molly's "ancestress of 1777" (ch. 28) is strange and graphic evidence that the Virginian's wooing of Molly is the wooing of American history. What he aims to beget on maid and history is a new people reformed along the strenuous lines of aristocratic quality rather than along the weak lines of democratic equality. Wister will stand godfather to the issue.

Mitchell undervalues the evocative power of The Virginian and underestimates the contextual awareness of the 
novel's original audience by suggesting that they would only know the immediate headline context of Wyoming's bid for statehood and its constitutional inclusion of female suffrage. They would have been familiar with the elements of the typological agenda as well. The richer literary and historical ramifications, some posted by Wisterian design, some automatic with "the matter of Virginia," make The Virginian an interesting book indeed-certainly capable of, and perhaps actually successful in, doing more than the "two things at once" (67) in Mitchell's estimate.

\section{Michael Kreyling \\ Vanderbilt University}

\section{Reply:}

Michael Kreyling's letter calls for little in the way of response. His terms are inexact (his is hardly a "typological" approach). His main point has been anticipated by others in standard readings of the novel (starting with Douglas Branch half a century ago). And he is prone to contentious assertions that are either wrong (Wister's reference to "the Virginian" patently does "leave his main figure "unnamed" '); misleading (I never imply my interpretation was the "only" one available to the novel's first readers); or unhelpfully silly ("Wisterical"?). Most important, if Kreyling aspires to debate constructively, he should focus more closely on the question raised by the author he chides. I remind him that in this case that question was, Why did Wister's novel fail to fit the popular formula it inspired? Nothing Kreyling says helps explain that failure or makes it any less baffling.

\section{Lee Clark Mitcheli}

Princeton University

\section{Social Reality}

\section{To the Editor:}

Sandy Petrey's article "Castration, Speech Acts, and the Realist Difference: $S / Z$ versus Sarnasine" (102 [1987]: 153-65) is a stimulating contribution to the current debate about realism. A difficulty arises, however, from the claim that the "dissociation of the constative from its referent furnishes a way to separate realist mimesis from the referential fallacy as well"' (155). It seems to me that Petrey is merely shifting the locus of that fallacy in his argument that "realism enacts a constative vision of the world by simultaneously denying language's connection to objective truth and affirming its expression of social truth" (155).

The concept of the "social" recurs throughout the article in a variety of forms: "social reality" (157); "not physical realities but social fabrications" (157); "[t]he process of meaning in Sarrasine is not the road to objective reality but the expression of what society accepts as real" (162); "social consensus" (164). In every instance a "social" reality is played off against an "objective" or "physical" reality. In the very act of dethroning objective reality as the referent for the literary text, Petrey appears to be enthroning another-undefined-social reality as the arbiter of authority.

What needs to be addressed is the ontological status of the category "social." Petrey's argument would be more persuasive if he were willing to push it a step further through the recognition that "society" and "social" are themselves products of the text. At more than one point in the article he seems on the verge of such a recognition, for example, when he emphasizes that "Sarrasine certainly negates all its affirmations of sexual identity, but not 'as uttered,' not before establishing a context in which their constative validity is secure" (156) and that "Sarrasine is a fully developed demonstration that words name not in fact but only in communities" (157). It is essential to acknowledge that the communities in question here are internal to the text, which establishes its own context to ensure the validity of the constative utterance. It does this by positing an internal field of reference, which acts as a cognitive frame for the formation of consensus, that is, "the idea others form of it," in the phrase Petrey cites from Balzac (157).

If the realist fallacy is not to be reinstated in another form, those "others," who collectively make up society, and on whose reading the fact depends, must be seen as intrinsic to the text. In $S / Z$, Petrey maintains, "what is real in realism are those textual elements deprived of meaning" (164). But having been deprived of referential meaning, they are reinvested with an "other" meaning created within the parameters of the text and contained in its codes.

\section{LIILAN R. FURST \\ University of North Carolina, Chapel Hill}

\section{Reply:}

Lilian Furst is correct to bring to the foreground what my article left implicit: every definition of reality in a literary text necessarily addresses a textual ontology, "an internal field of reference, which acts as a cognitive frame" during the reading experience rather than for all time. Social reality in and of itself authorizes realist discourse no more than does physical reality. Balzac's contradictory names for a single character become facts because the work in which they appear establishes (rather than reproduces) contexts in which their validity is secure, and my article should indeed have paid more attention to how this establishment takes effect.

Yet I disagree with what I take to be Furst's assump- 